\title{
KINERJA PENYULUH PERTANIAN TERHADAP KELOMPOK TANI "SUKA MAJU" DI DESA KOPIWANGKER KECAMATAN LANGOWAN BARAT
}

\author{
Grasela Venda Wosal \\ Martha Mareyke Sendow \\ Lorraine W. Th. Sondakh
}

\begin{abstract}
This study aims to determine the performance of agricultural extension workers to "Suka Maju" farmers groups in the village Kopiwangker sub-district, west Langowan. This research was conducted for two months from December 2016 to January 2017. The data used in this study are primary data and secondary data. Primary data obtained through direct interviews with members of the farmer group as many as 23 people based on questionnaires and secondary data obtained from the office of the agricultural, fisheries and forestry extension office (BP3K). The results of this study show that the performance of 2 agricultural extension workers in kopiwangker village is quite good with a score interpretation of $65.76 \% . *$ eprm*.
\end{abstract}

Keywords: performance concept, agricultural extension officers, farmer groups, "forward", kopiwangker Village.

\begin{abstract}
ABSTRAK
Penelitian ini bertujuan untuk mengetahui kinerja penyuluh pertanian terhadap kelompok tani "Suka Maju" di Desa Kopiwangker Kecamatan Langowan Barat. Penelitian ini dilakukan selama dua bulan dari bulan Desember 2016 sampai bulan Januari 2017. Data yang digunakan dalam penelitian ini yaitu data primer dan data sekunder. Data primer diperoleh melalui wawancara langsung kepada anggota kelompok tani sebanyak 23 orang berdasarkan kuesioner dan Data sekunder diperoleh dari Kantor Balai Penyuluhan Pertanian, Perikanan dan Kehutanan (BP3K). Hasil penelitian ini menunjukkan bahwa kinerja kedua orang penyuluh pertanian di Desa Kopiwangker tergolong cukup baik dengan interpretasi skor $65,76 \%$.*prm*.
\end{abstract}

Kata kunci: konsep kinerja, penyuluh pertanian, kelompok tani “Suka Maju”, Desa Kopiwangker.

\section{PENDAHULUAN}

\section{Latar Belakang}

Peranan sektor pertanian dalam perekonomian sangat penting dan strategis. Hal ini terutama karena sektor pertanian masih memberikan lapangan pekerjaan bagi sebagian besar penduduk yang ada di pedesaan dan menyediakan bahan pangan bagi penduduk. Peranan lain dari sektor pertanian adalah menyediakan bahan mentah bagi industri dan menghasilkan devisa negara melalui ekspor non migas. Bahkan sektor pertanian mampu menjadi katup pengaman perekonomian nasional dalam menghadapi krisis ekonomi yang melanda Indonesia dalam satu dasawarsa terakhir ini. Kontribusi penting penyuluhan pertanian untuk meningkatkan pembangunan pertanian dan peningkatan produksi pangan yang telah menyebabkan cepatnya perkembangan minat orang dalam penyuluhan selama beberapa dekade terakhir. Jadi, sektor pertanian adalah sektor yang mau tidak mau harus ada dan berkembang, karena bukan hanya urusan pendapatan Negara tapi juga kelangsungan hidup manusia. Kondisi sosial budaya petani, merupakan masalah utama dalam fungsi sektor pertanian di dalam pembangunan nasional dan kemampuan sektor tersebut untuk bersaing pada abad yang akan datang (Oudejans, 2006).

Kinerja sebagai catatan outcome yang dihasilkan dari fungsi pegawai tertentu dan kontribusi anggota organisasi terhadap organisasinya, yang dapat diukur dengan penilaian kinerja sebagai gerakan perbuatan, pelaksanaan kegiatan atau tindakan sadar yang 
diarahkan untuk mencapai suatu tujuan atau target tertentu. Tanpa adanya kinerja berarti tidak ada upaya untuk mencapai hasil atau target dan tidak akan terjadi suatu perubahan sedikitpun, dari kualitas kinerja nantinya akan berpengaruh kepada hasil. Kinerja yang baik memiliki beberapa karakteristik yaitu rasional, konsisten, tepat, efisien, terarah, disiplin dengan waktu dan berorientasi pada kerjasama kelompok. Jadi, kinerja merupakan implementasi dari rencana yang telah disusun melalui kinerja yang bersumber daya manusia dan memiliki kemampuan, kompetensi, motivasi dan kepentingan dengan menghargai dan memperlakukan sumber daya manusianya supaya mempengaruhi sikap dan perilakunya dalam menjalankan suatu kinerja (Bernardin \& Russel dalam Mardikanto, 1993).

Begitu juga dengan kelompok tani yang ada di Desa Kopiwangker Kecamatan Langowan Barat yang tidak luput dari penyuluh pertanian yang berada di BP3K (Balai Penyuluhan Pertanian, Perikanan dan Kehutanan) yang daerahnya sebagian besar penduduknya bekerja sebagai petani, untuk menunjang usahanya terdapat kelompok-kelompok tani yang termasuk di dalamnya kelompok tani "suka maju" sebagai wadah berkumpulnya para petani yang memiliki tujuan bersama, yaitu ingin mengubah kehidupan sosial menjadi lebih sejahtera. Desa Kopiwangker pada umumnya memiliki tiga (3) kelompok tani yaitu Tumou tou, Esa keter dan Suka maju.oleh karena kelompok tani yang lain sudah tidak aktif maka hanya di ambil satu kelompok tani yang aktif yaitu kelompok tani suka maju, Kelompok Tani suka maju memiliki anggota kelompok tani berjumlah 23 anggota. Adapun usaha-usaha tani dari kelompok suka maju yaitu padi sawah, jagung, tomat, batang bawang, dan cabe. Dengan usaha tani dari kelompok tani suka maju ini diharapkan dapat mengatasi atau mengurangi masalah-masalah yang di hadapi sehingga dapat meningkatkan produksi hasil pertanian dan optimasi lahan dapat meningkat. Untuk mengetahui kinerja penyuluhan pertanian ditingkat lapangan maka perlu dilakukan penelitian terhadap penyuluh pertanian, Dengan melakukan penelitian ini akan terlihat keberhasilan dan kekurangan dari kinerja penyuluh pertanian yang telah dilakukan dan menjadi bahan masukan pada penyuluh pertanian untuk selanjutnya.
Beberapa kemampuan penyuluh yang di pandang petani perlu di tingkatkan adalah pemahaman yang baik terhadap potensi sumber daya di wilayah binaan penyuluh, budaya dan kebutuhan masyarakat petani. Untuk mengetahui sampai sejauh mana keberhasilan kinerja penyuluh pertanian di tingkat lapangan, maka perlu dilakukan penelitian terhadap penyuluh pertanian. Dilapangan persepsi sebagian besar petani terhadap kemampuan penyuluh yang terkait dengan penguasaan penyuluh mengenai teknik budidaya komoditas pertanian di nilai memadai termasuk pengetahuan produksi, tanaman, dan ternak. Penyuluh di nilai mampu menjelaskan inovasi suatu teknologi dan dapat berkomunikasi dengan bahasa yang mudah di pahami petani (BP3K Kecamatan Langowan Barat, 2016).

\section{Rumusan Masalah}

Berdasarkan latar belakang yang telah di kemukakan maka yang menjadi perumusan masalah dalam penelitian ini ialah bagaimana kinerja penyuluh pertanian terhadap kelompok Tani "Suka Maju" di Desa Kopiwangker Kecamatan Langowan Barat?

\section{Tujuan Penelitian}

Penelitian ini bertujuan untuk mengetahui kinerja penyuluh pertanian terhadap kelompok Tani "Suka Maju" di Desa Kopiwangker Kecamatan Langowan Barat.

\section{Manfaat Penelitian}

Penelitian ini di harapkan bermanfaat untuk mengembangkan kinerja penyuluh pertanian pada kelompok tani, khususnya di Desa Kopiwangker Kecamatan Langowan Barat dan boleh memberikan informasi bagi pihak yang membutuhkan informasi sehubungan dengan penelitian ini.

\section{METODE PENELITIAN}

\section{Waktu dan Lokasi Penelitian}

Penelitian ini telah dilakukan di Desa Kopiwangker Kecamatan Langowan Barat. Penelitian berlangsung selama dua bulan yaitu bulan Desember 2016 sampai bulan Januari 2017 di mulai dari persiapan sampai dengan laporan hasil penelitian. 


\section{Metode Pengumpulan Data}

Penelitian ini menggunakan data primer dan data sekunder. Data primer di peroleh melalui wawancara langsung pada Kelompok Tani Suka Maju berdasarkan daftar pertanyaan yang telah di siapkan (kuesioner), Jumlah responden yang di ambil yaitu 23 anggota kelompok tani, sedangkan data sekunder diperoleh melalui instansi-instansi yang berkaitan dengan penelitian ini antara lain di kantor BP3K Kecamatan Langowan Barat.

\section{Konsep Pengukuran Variabel}

Variabel kinerja penyuluh pertanian yang di ukur sebagai berikut:

1. Tersusunnya data potensi wilayah

a. Menemukan potensi wilayah

b. Pembuatan peta wilayah kerja

c. Keterlibatan dalam potensi

2. Tersusunnya program penyuluh pertanian
a. Penyusunan bahan program
b. Pencetakan materi
c. Pelaksanaan program

3. Terdesiminasinya info teknologi pertanian pada pelaku utama.
a. Penyebaran informasi
b. Kunjungan / tatap muka
c. Melakukan metode penerapan dalam bentuk demonstrasi

4. Tumbuh kembangnya kelembagaan petani
a. Kelompok tani pemula ke lanjut
b. Pengembangan jumlah kelompok tani
c. Peningkatan ketrampilan kelompok tani

5. Meningkatnya kapasitas pelaku utama
a. Jumlah anggota yang mengikuti latihan
b. Peningkatan kualitas dan kuantitas demplot
c. Peningkatan kesejahteraan petani

6. Meningkatnya akses pelaku utama terhadap info pasar, teknologi dan pembiayaan.
a. Pembentukan jejaring antar kelompok tani
b. Memberi info pasar
c. Pengembangan kemitraan

7. Meningkatnya produksi dan pendapatan pelaku utama
a. Peningkatan produksi
b. Peningkatan pendapatan kelompok tani
c. Peningkatan pendapatan keluarga kelompok tani

\section{Metode Analisis Data}

Analisis data yang digunakan dalam penelitian ini adalah skala likert untuk mengetahui kinerja penyuluh pertanian terhadap anggota kelompok Tani Suka Maju di Desa Kopiwangker. Menurut Soegiyono dalam Sunyoto (2012) skala likert adalah skala yang digunakan untuk mengukur sikap, pendapat, dan persepsi seseorang atau kelompok orang tentang fenomena seseorang.

Dalam skala Likert, variabel yang diukur dijabarkan menjadi indikator variabel. Kemudian indikator tersebut di jadikan sebagai titik tolak untuk menyusun item-item instrument yang dapat berupa pernyataan-pernyataan. Dalam penelitian ini di susun 21 pernyataan dan jawaban setiap instrumen berupa kata-kata, yaitu:

$$
\begin{aligned}
\mathrm{B} & =\text { Baik } \\
\mathrm{CB} & =\text { Cukup Baik } \\
\mathrm{TB} & =\text { Tidak Baik }
\end{aligned}
$$

Bila:

$$
\begin{array}{ll}
\text { B } & \text { diberi skor }=3 \\
\text { CB } & \text { diberi skor }=2 \\
\text { TB } & \text { diberi skor }=1
\end{array}
$$

Dengan cara perhitungan skor masingmasing pernyataan:

Maka jumlah skor tiap kriteria = capaian skor $\mathrm{X}$ jumlah responden.

$$
\begin{aligned}
& \mathrm{S} 3=3 \times 23=69 \\
& \mathrm{~S} 2=2 \times 23=46 \\
& \mathrm{~S} 1=1 \times 23=23
\end{aligned}
$$

Jumlah skor ideal untuk setiap pernyataan skor $($ tertinggi $)=69$ dan jumlah skor $($ terendah $)=23$

Cara perhitungan skor keseluruhan untuk mengetahui kinerja penyuluh pertanian:

Jumlah skor seluruh kriterium = capaian jumlah skor $\mathrm{x}$ jumlah responden $\mathrm{x}$ instrumen pernyataan.

$$
\begin{aligned}
& \mathrm{S} 3=3 \times 23 \times 21=1,449 \\
& \mathrm{~S} 2=2 \times 23 \times 21=966 \\
& \mathrm{~S} 1=1 \times 23 \times 21=483
\end{aligned}
$$

Jumlah skor ideal untuk keseluruhan pernyataan = 1,449 (tinggi) dan jumlah skor (rendah) $=483$

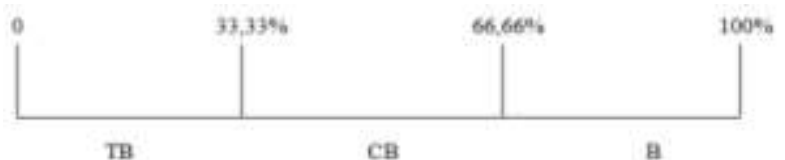

Keterangan kriteria interpretasi skor :

$$
\begin{array}{ll}
\text { Angka 0\% - 33,33\% } & =\text { Tidak Baik } \\
\text { Angka 33,33\%-66,66\% } & =\text { Cukup Baik } \\
\text { Angka 66,66\%-100\% } & =\text { Baik }
\end{array}
$$

\section{HASIL DAN PEMBAHASAN}

\section{Deskripsi Wilayah Penelitian}

\section{Letak dan Luas Wilayah}

Desa Kopiwangker adalah salah satu Desa di Kecamatan Langowan Barat, dengan Luas Wilayah 62 ha yang terdiri dari 4 jaga. Adapun batas-batas desa yaitu, 
1. Sebelah utara berbatasan dengan Desa Taraitak

2. Sebelah selatan berbatasan dengan Desa Lowian

3. Sebelah barat berbatasan dengan Desa Lowian

4. Sebelah timur berbatasan dengan Desa Paslaten

\section{Jumlah Penduduk}

Tabel 1. Jumlah Penduduk Desa Kopiwangker

\begin{tabular}{lcc}
\hline \multicolumn{1}{c}{ Jenis Kelamin } & Jumlah Jiwa & Persentase (\%) \\
\hline Laki-laki & 551 & 52,13 \\
Perempuan & 506 & 47,87 \\
\hline Jumlah & 1057 & 100 \\
\hline
\end{tabular}

Sumber: Diolah dari data primer, 2018

\section{Mata Pencaharian}

Masyarakat di Desa Kopiwangker Kecamatan Langowan Barat memiliki mata pencaharian sebagai petani, pegawai negeri sipil, pedagang, wiraswasta dan lain-lain.

Tabel 2. Jumlah Mata Pencaharian Penduduk

\begin{tabular}{llcc}
\hline No & Mata Pencaharian & Jumlah & Persentase (\%) \\
\hline 1 & PNS & 79 & 10 \\
2 & Petani & 432 & 55 \\
3 & Pedagang & 271 & 35 \\
4 & Dan Lain-Lain & & \\
\hline \multicolumn{2}{l}{ Jumlah } & 1057 & 100 \\
\hline
\end{tabular}

Sumber: Diolah dari data primer, 2018

Total jumlah penduduk di Desa Kopiwangker Kecamatan Langowan Barat adalah 1057 jiwa. Sedangkan yang memiliki mata pencaharian sebagai petani lebih banyak dari pada pedagang dan PNS, hal ini dapat dilihat dari jumlah persentase sebesar 55\%, pedagang sebesar $35 \%$ dan PNS sebesar 10\% dengan jumlah penduduk yang memiliki mata pencaharian sebesar 782 jiwa. Sedangkan 275 jiwa belum memiliki pekerjaan karena terdiri dari anak-anak SD, SMP, SMA dan Mahasiswa.

\section{Karakteristik Kelompok Tani}

Tabel 3. Karakteristik Kelompok Tani

\begin{tabular}{ccccc}
\hline No & $\begin{array}{c}\text { Kelompok } \\
\text { Tani }\end{array}$ & $\begin{array}{c}\text { Luas } \\
\text { Lahan (ha) }\end{array}$ & $\begin{array}{c}\text { Jumlah } \\
\text { Anggota }\end{array}$ & $\begin{array}{c}\text { Tahun } \\
\text { Berdiri }\end{array}$ \\
\hline 1 & Suka Maju & 20 & 23 & 2002 \\
2 & Tumou Tou & 20 & 23 & 2006 \\
3 & Esa Keter & 15 & 15 & 2013 \\
\hline \multicolumn{5}{l}{ Sumber: Diolah dari data primer, 2018 }
\end{tabular}

Karakteristik Responden

Jumlah responden dalam penelitian ini adalah 23 anggota kelompok tani. Gambaran umum mengenai responden di sajikan menurut umur, jenis kelamin dan tingkat pendidikan.

\section{Umur Responden}

Kemampuan bekerja atau melakukan aktivitas fisik seseorang dapat di pengaruhi oleh faktor umur. Setiap responden sudah pasti tidak sama, demikian juga dengan umur dari masingmasing responden. Berikut adalah variasi umur dari tiap responden, Tabel 4 menunjukkan jumlah responden terbanyak adalah umur 41-50 tahun dengan jumlah 9 responden dengan presentase sebesar $39,13 \%$.

\begin{tabular}{llcc}
\multicolumn{5}{l}{ Tabel 4. Jumlah Responden Menurut Umur } \\
\hline No & $\begin{array}{l}\text { Umur } \\
\text { (Tahun) }\end{array}$ & $\begin{array}{c}\text { Jumlah } \\
\text { Responden }\end{array}$ & Persentase (\%) \\
\hline 1 & $31-40$ & 4 & 17.39 \\
2 & $41-50$ & 5 & 21.73 \\
3 & $51-60$ & 3 & 13.04 \\
4 & $61-70$ & 7 & 30.43 \\
5 & $71-80$ & 4 & 17.39 \\
\hline & Jumlah & 23 & 100 \\
\hline
\end{tabular}

\section{Tingkat Pendidikan}

Pendidikan sangat penting dalam usaha peningkatan kualitas penduduk karena berguna bagi pembangunan pribadi serta peningkatan intelektual dan wawasan seseorang. Tingkat pendidikan dari masing-masing orang berbeda, begitu juga dengan tingkat pendidikan dari responden.

Tabel 5 menunjukkan bahwa tingkat pendidikan responden terbanyak yaitu pada pendidikan tinkat SMP dengan jumlah 15 responden dengan presentase $65,21 \%$ sedangkan tingkat pendidikan paling sedikit adalah pendidikan tingkat SD dengan jumlah 3 responden dengan presentase $13,04 \%$.

Tabel 5. Jumlah Responden Menurut Tingkat Pendidikan

\begin{tabular}{llcc}
\hline No & Pendidikan & Jumlah Responden & Persentase (\%) \\
\hline 1 & SD & 3 & 13.04 \\
2 & SMP & 15 & 65.21 \\
3 & SMA & 5 & 21.73 \\
\hline & Jumlah & 23 & 100 \\
\hline
\end{tabular}

Hasil tabulasi atas variabel tersusunnya data potensi wilayah, dapat dilihat pada Table 6 . Penjelasan mengenai tersusunnya data potensi wilayah serta indikator-indikator pendukung akan dipaparkan sebagai berikut. 


\section{Kinerja Penyuluh Pertanian Terhadap Kelompok Tani Suka Maju}

\section{Rekapitulasi Tupoksi Tersusunnya Data Potensi Wilayah}

Hasil perhitungan seluruh tupoksi data potensi wilayah, maka disajikan rekapitulasi sebagai berikut.

Tabel 6. Rekapitulasi Pengukuran Tupoksi Tersusunnya Data Potensi Wilayah

\begin{tabular}{llcc}
\hline No & Tupoksi & Total Skor & Interpretasi \\
\hline 1 & Menemukan potensi wilayah & 33 & Tidak Baik \\
2 & Pembuatan peta wilayah kerja & 46 & Cukup Baik \\
3 & Keterlibatan dalam potensi & 26 & Tidak Baik \\
\hline
\end{tabular}

Tabel 6 menunjukkan bahwa terdapat 3 indikator pembentukan data potensi dimana tupoksi pembuatan peta wilayah kerja mendapat interpretasi cukup baik sedangkan menemukan potensi wilayah dan keterlibatan dalam potensi mendapat interpretasi tidak baik.

\section{Rekapitulasi Tupoksi Program Penyuluh Pertanian}

Hasil perhitungan seluruh tupoksi data potensi wilayah maka rekapitulasi sebagai berikut.

Tabel 7. Rekapitulasi Pengukuran Tupoksi Program Penyuluh Pertanian

\begin{tabular}{llcc}
\hline No & Tupoksi & Total Skor & Interpretasi \\
\hline 1 & Penyusunan bahan program & 23 & Tidak Baik \\
2 & Pencetakan materi & 46 & Cukup Baik \\
3 & Pelaksanaan program & 46 & Cukup Baik \\
\hline
\end{tabular}

Tabel 7 menunjukkan bahwa terdapat 3 tupoksi pembentukan program penyuluh pertanian yaitu penyusunan bahan program, pencetakan materi dan pelaksanaan program mendapat interpretasi cukup baik.

\section{Rekapitulasi Tupoksi Terdesiminasinya Info Teknologi Pertanian Kepada Pelaku Utama}

Hasil perhitungan seluruh tupoksi terdesiminasinya info teknologi pertanian kepada pelaku utam maka disajikan rekapitulasi sebagai berikut.

Tabel 8. Rekapitulasi Pengukuran Tupoksi Terdesiminasinya Info Teknologi Pertanian Kepada Pelaku Utama

\begin{tabular}{llcc}
\hline No & Tupoksi & Total Skor & Interpretasi \\
\hline 1 & Penyebaran informasi & 46 & Cukup Baik \\
2 & Kunjungan / tatap muka & 46 & Cukup Baik \\
3 & Metode demonstrasi & 23 & Tidak Baik \\
\hline
\end{tabular}

Tabel 8 menunjukkan bahwa terdapat 3 indikator dimana tupoksi penyebaran informasi dan kunjungan/tatap muka mendapat interpretasi cukup baik, sedangkan metode demonstrasi kepada kelompok tani mendapatkan interpretasi tidak baik.

\section{Rekapitulasi Tupoksi Tumbuh Kembangnya Kelembagaan Petani}

Hasil perhitungan seluruh tupoksi data potensi wilayah yang disajikan sebagai berikut.

\begin{tabular}{llcc} 
Tabel & $\begin{array}{c}\text { 9. } \\
\text { Rekapitulasi } \\
\text { Kembangnya Kelembagaan Petani }\end{array}$ & \multicolumn{1}{c}{$\begin{array}{c}\text { Pengukuran } \\
\text { Variabel }\end{array}$} & Tumbuh \\
\hline No & Tupoksi & Total Skor & Interpretasi \\
\hline 1 & $\begin{array}{l}\text { Kelompok tani pemula } \\
\text { ke lanjut }\end{array}$ & 46 & Cukup Baik \\
2 & $\begin{array}{l}\text { Pengembangan jumlah } \\
\text { kelompok tani }\end{array}$ & 23 & Tidak Baik \\
3 & $\begin{array}{l}\text { Peningkatan ketrampilan } \\
\text { kelompok tani }\end{array}$ & 46 & Cukup Baik
\end{tabular}

Tabel 9 menunjukkan bahwa ada 3 indikator pembentukan tumbuh kembangnya kelembagaan petani dimana tupoksi kelompok tani pemula ke lanjut, pengembangan jumlah kelompok tani dan peningkatan ketrampilan kelompok tani mendapatkan interpretasi cukup baik.

\section{Rekapitulasi Variabel Meningkatnya Kapasitas Pelaku Utama \\ Hasil perhitungan seluruh tupoksi} meningkatnya pelaku utama, maka rekapitulasinya sebagai berikut.

Tabel 10. Rekapitulasi Pengukuran Tupoksi Meningkatkan Kapasitas Pelaku Utama

\begin{tabular}{llcc}
\hline No & Tupoksi Interpretasi \\
\hline 1 & $\begin{array}{l}\text { Jumlah anggota yang } \\
\text { mengikuti pelatihan }\end{array}$ & 46 & Cukup Baik \\
2 & $\begin{array}{l}\text { Peningkatan kualitas } \\
\text { dan kuantitas demplot }\end{array}$ & 46 & Cukup Baik \\
3 & $\begin{array}{l}\text { Peningkatan } \\
\text { kesejahteraan petani }\end{array}$ & 46 & Cukup Baik \\
\hline
\end{tabular}

Tabel 10 menunjukkan bahwa terdapat 3 indikator meningkatkan kapasitas pelaku utama dimana tupoksi jumlah anggota yang mengikuti pelatihan, peningkatan kualitas dan kuantitas demplot dan peningkatan kesejahteraan petani mendapatkan interpretasi cukup baik.

\section{Rekapitulasi Tupoksi Meningkatnya Akses Pelaku Utama Pada Info Pasar, Teknologi dan Pembiayaan}

Hasil perhitungan seluruh tupoksi disajikan rekapitulasi sebagai berikut.

Tabel 11. Rekapitulasi Pengukuran Tupoksi Meningkatnya Akses Pelaku Utama

\begin{tabular}{llcc}
\hline No & Tupoksi & Total Skor & Interpretasi \\
\hline 1 & $\begin{array}{l}\text { Pembentukan jejaring } \\
\text { antar kelompok tani }\end{array}$ & 63 & Baik \\
2 & $\begin{array}{l}\text { Memberi informasi } \\
\text { pasar }\end{array}$ & 26 & Tidak Baik \\
3 & $\begin{array}{l}\text { Pengembangan } \\
\text { kemitraan }\end{array}$ & 69 & Baik \\
\hline
\end{tabular}


Tabel 11 menunjukkan bahwa 3 tupoksi meningkatnya akses terhadap informasi pasar, teknologi dan pembiayaan dimana pernyataan pembentukan jejaring antar kelompok tani dan pengembangan kemitraan mendapatkan interpretasi baik dan tupoksi memberi informasi pasar mendapatkan interpretasi cukup baik.

\section{Rekapitulasi Tupoksi Meningkatnya Produksi dan Pendapatan Pelaku Utama}

Hasil perhitungan seluruh tupoksi disajikan rekapitulasi sebagai berikut.

\begin{tabular}{|c|c|c|c|}
\hline No & Tupoksi & Total Skor & Interpretasi \\
\hline 1 & Peningkatan produksi & 69 & Baik \\
\hline 2 & $\begin{array}{l}\text { Peningkatan } \\
\text { pendapatan kelompok } \\
\text { tani }\end{array}$ & 69 & Baik \\
\hline 3 & $\begin{array}{l}\text { Peningkatan } \\
\text { pendapatan keluarga } \\
\text { tani }\end{array}$ & 69 & Baik \\
\hline
\end{tabular}

Tabel 12 menunjukkan bahwa terdapat 3 indikator meningkatnya produksi dan pendapatan pelaku utama, dimana tupoksi peningkatan produksi, peningkatan pendapatan kelompok tani dan peningkatan pendapatan keluarga kelompok tani mendapat interpretasi baik.

\section{Rekapitulasi Indeks Kinerja Penyuluh Pertanian Terhadap Kelompok Tani Suka Maju di Desa Kopiwangker Masing-Masing Tupoksi dan Interpretasi Hasil}

Penelitian ini untuk mengukur kinerja penyuluh pertanian terhadap kelompok tani suka maju di desa kopiwangker kecamatan langowan barat dengan mengambil 21 tupoksi sebagai tolak ukur dalam penelitian ini.

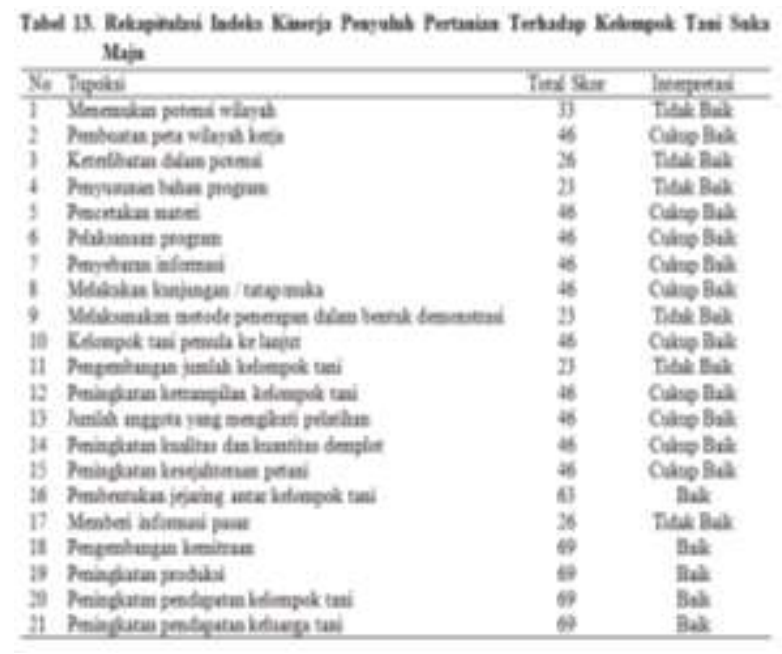

Tabel 13 tersebut menyatakan tupoksi menemukan potensi wilayah, keterlibatan dalam potensi, penyusunan bahan program, melaksanakan metode penerapan dalam bentuk demonstrasi, pengembangan jumlah kelompok tani dan pembentukan jejaring antar kelompok tani mendapatkan hasil terendah dari 21 indikator lainnya, hal ini di karenakan tupoksi menemukan potensi wilayah tergolong tidak baik karena untuk menemukan potensi wilayah yang seharusnya ditemukan oleh penyuluh pertanian, namun hanya ditemukan oleh kelompok tani sendiri. Dan tupoksi keterlibatan dalam potensi tergolong tidak baik karenapenyuluh pertanian kurang berpartisipasi dalam melibatkan diri dalam menemukan potensi. Tupoksi penyusunan bahan program tergolong tidak baik karena semua responden atau kelompok tani tidak terbantu dengan adanya bahan program yang di buat oleh penyuluh pertanian sehingga tujuan yang akan dicapai tidak di ketahui oleh kelompok tani. Dan tupoksi melaksanakan metode penerapan dalam bentuk demonstrasi tergolong tidak baik karena penyuluh pertanian masih kurang melakukan metode demonstrasi, penyuluh masih kurang berkemampuan sehingga kelompok tani ada yang memakai cara alaminya dari pada demonstrasi yang dilakukan oleh penyuluh pertanian. Dan pengembangan jumlah kelompok tani tergolong tidak baik karena dari tahun ke tahun tidak terlihat pengembangan jumlah kelompok tani yang ada di desa kopiwangker. Dan memberi informasi pasar tergolong tidak baik di karenakan kelompok tani mendapatkan informasi harga pasar dan jumlah kebutuhan pasar. Sedangkan dari 3 responden menyatakan kerja dari penyuluh dalam hal member informasi pasar tidak baik karena kelompok tani mendapat informasi terlebih dahulu dari penyuluh pertanian.

Selanjutnya tupoksi pembentukan jejaring antar kelompok tani tergolong baik, artinya tugas penyuluh dalam membangun kerja sama antar petani baik, karena setiap anggota kelompok tani saling membutuhkan. Dan tupoksi pengembangan kemitraan tergolong baik, artinya upaya yang dilakukan oleh penyuluh pertanian dalam hal membangun kerjasama dengan pihak luar baik sehingga pelaku utama akan mudah bekerjasama dengan lainnya dan membuat perjanjian tertulis atau kesepakatan. Dan tupoksi peningkatan produksi tergolong baik karena terjadi peningkatan produksi pada usaha tani dari kelompok tani suka maju yang terlihat dari tahun 
ke tahun perkembangannya. Dan tupoksi peningkatan pendapatan kelompok tani tergolong baik karena dilihat dari peningkatan produksi pada usaha tani dari kelompok tani suka maju tentu pendapatan dari kelompok tani juga meningkat. Dan tupoksi peningkatan pendapatan keluarga kelompok tani tergolong baik, karena setiap keluarga kelompok tani merasakan dampak dari peningkatan hasil pertanian dari kelompok tani sehingga mereka memberikan apresiasi kepada penyuluh pertanian karena telah membantu kelompok tani dalam usaha peningkatan pendapatan dari kelompok tani yang berdampak pada pendapatan keluarga kelompok tani tersebut.

Hasil untuk mengetahui kinerja dari penyuluh pertanian terhadap kelompok tani suka maju, maka perlu dihitung jumlah keseluruhan skor pada setiap kriterium. Jumlah skor hasil penelitian ini mencapai 953. Dan jumlah skor ideal (skor tertinggi) adalah 1.449 dan jumlah skor terendah yaitu 217 (rendah). Berdasarkan data yang diambil dari 21 tupoksi yang diajukan pada 23 responden, maka letak kinerja penyuluh pertanian terhadap kelompok tani suka maju terletak pada:

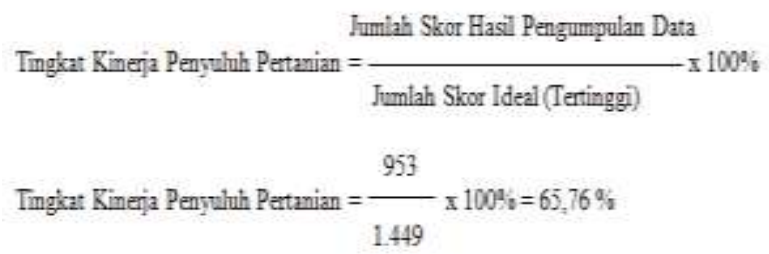

Dengan interpretasi nilai :

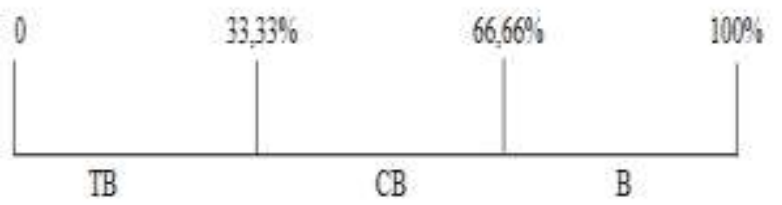

Keterangan kriteria interpretasi skor

Angka 0\%-33.33\% = Tidak Baik

Angka 33.33\% - 66.66\% = Cukup Baik

Angka $66.66 \%-100 \%=$ Baik

Hasil perhitungan di atas menunjukkan kinerja penyuluh pertanian terhadap kelompok tani suka maju di desa kopiwangker kecamatan langowan barat $65,76 \%$. Artinya penyuluh pertanian secara umum tergolong cukup baik karena dilihat dari 21 tupoksi dimana 5 tupoksi di kategorikan baik, 10 tupoksi cukup baik dan 6 tupoksi tidak baik.
Kinerja penyuluh pertanian pada wilayah binaan perlu di tingkatkan lagi, maka penyulu pertanian harus memperhatikan tugas dan fungsi penyuluh pada tupoksi di atas yaitu: data potensi, program penyuluh pertanian, terdesiminasinya info teknologi pertanian, tumbuh kembangnya kelembagaan petani, meningkatnya kapasitas pelaku utama, meningkatnya akses pelaku utama terhadap informasi pasar, teknologi dan pembiayaan dan meningkatnya produksi dan pendapatan pelaku utama.

\section{KESIMPULAN DAN SARAN}

\section{Kesimpulan}

Hasil penelitian ini menunjukkan kinerja penyuluh pertanian terhadap kelompok Tani "Suka Maju" di Desa Kopiwangker Kecamatan Langowan Barat tergolong cukup baik berdasakan 21 Tupoksi yang di teliti. dimana 5 dikategorikan baik, 10 tupoksi cukup baik, dan 6 tupoksi tidak baik. Kinerja dari penyuluh pertanian pada wilayah binaan perlu di tingkatkan, maka penyuluh pertanian harus memperhatikan tugas dan fungsi penyuluh pada ketujuh tupoksi di atas yaitu: data potensi, program penyuluh pertanian, terdesiminasinya info teknologi pertanian, tumbuh kembangnya kelembagaan petani, meningkatnya kapasitas pelaku utama, meningkatnya akses pelaku utama terhadap informasi pasar, teknologi dan pembiayaan, meningkatnya produksi dan pendapatan pelaku utama.

\section{Saran}

Kinerja penyuluh pertanian perlu di tingkatkan lagi, khususnya kelompok Tani "Suka Maju" di Desa Kopiwangker Kecamatan Langowan Barat karena dari hasil penelitian ini menunjukkan berada pada kategori cukup baik, sedangkan masih ada satu kategori yang paling tinggi yaitu kategori baik. Dalam hal ini Penyuluh pertanian harus memperhatikan tugas dan fungsi penyuluh pada tupoksi penyuluh pertanian terlebih khusus tupoksi yang dinilai petani tergolong tidak baik seperti; menemukan potensi wilayah, keterlibatan dalam potensi, penyusunan bahan program, melaksanakan metode penerapan dalam bentuk demonstrasi, pengembagan jumlah kelompok tani, dan memberi informasi pasar. 


\section{DAFTAR PUSTAKA}

BP3K, Kecamatan Langowan Barat. 2016.

Mardikanto, T. 1993. Penyuluhan Pembangunan Pertanian. Surakarta: Sebelas Maret University Press.
Oudejans Jan, H. M. 2006. Perkembangan Pertanian di Indonesia. UGM Press, Yogyakarta.

Sunyoto Danang. 2012. Konsep Dasar Riset Pemasaran \& Perilaku Konsumen. 